\title{
Pemberdayaan Masyarakat Melalui Kota Tanpa Kumuh
}

\author{
Esli Zuraidah Siregar \\ Fakultas Dakwah dan Ilmu Komunikasi IAIN Padangsidimpuan \\ (E-mail: esli.zuraidah@gmail.com)
}

\begin{abstract}
Slumless City Institution (KOTAKU) a form of community empowerment and development planned by the government to improve the welfare and comfort of people's lives. Slumless city activities are focused on the environment, human resources, social, health and especially education. Empowernment is focused on emproving welfare and poverty alleviation. Community empowerment through cities without slums is a national program was carried out in 271 regencies/cities in 34 propinces in Indonesia. This program was carrie out in stages to deal with 35,291 ha slum area. The KOTAKU program is similar to empowerment in general, which is focused on the community, but involves government officials and other influential parties. KOTAKU standards can be seen from the adequate facilities and infrastructure such as; fire adequate security, the existence of a broad public space according to standards, waste water management, environmental roads, and environmental drainage that is integrated the urban.
\end{abstract}

Keywords: Empowerment, Community, Seedy

Abstrak: Lembaga Kota Tanpa Kumuh (KOTAKU) suatu bentuk pemberdayaan dan pengembangan masyarakat yang direncanakan oleh pemerintah untuk meningkatkan kesejahteraan dan kenyamanan hidup masyarakat. Kegiatan Kota Tanpa Kumuh difokuskan pada lingkungan, sumber daya manusia, sosial, kesehatan dan utamanya pendidikan. Pemberdayaan difokuskan pada peningkatan kesejahteraan dan pengentasan kemiskinan. Pemberdayaan masyarakat melalui kota tanpa kumuh merupakan program Nasional yang dilakukan di 271 Kabupaten/Kota di 34 Propinsi di Indonesia. Program ini dilakukan secara bertahap untuk menangani wilayah pemukiman kumuh seluas 35.291 Ha. Program KOTAKU sama halnya dengan pemberdayaan pada umumnya yang terfokus pada masyarakat, namun melibatkan pejabat pemerintah dan pihak-pihak lain yang berpengaruh. Standar KOTAKU dilihat dari saranan dan prasarana yang memadai seperti; pengamanan kebarakan yang memadai, adanya ruang public yang luas sesuai standar, pengelolaan limbah air, jalan lingkungan, dan drainase lingkungan yang terintegrasi sampe ke Perkotaan.

Kata Kunci: Pemberdayaan, Masyarakat, Kumuh. 
147 Esli Zuraidah Siregar, Pemberdayaan Masyarakat Melalui Kota Tanpa Kumuh Jurnal At-Taghyir : Jurnal Dakwah dan Pengembangan Masyarakat Desa

Volume 2 Nomor 1 Desember 2019, h. 146-162

\section{A. Pendahuluan}

Berkembangnya pembangunan sosial untuk mengimbangi paradigm pembangunan ekonomi sosial maupun tatanan lingkungan sebagai suatu unsur sejahteranya suatu masyarakat, pemerintah melalui program Kota Tanpa Kumuh (KOTAKU), memberdayakan masyarakat melalui program tersebut. Secara umum pemberdayaan masyarakat bertujuan untuk memberikan daya kepada masyarakat, dari yang lemah menjadi kuat, meningkatkan keberdayaan dan kemandirian masyarakat. Konteks pembangunan dan pengentasan kemiskinan saat ini populer dengan istilah pemberdayaan. Pihak lemah (powerless) dan tidak berdaya merupakan suatu realitas yang pengembangkan konsep peberdayaan dikalangan masyarakat. Ketidakberdayaan dan kelemahan keterampilan, modal usaha, pengetahuan, pengalaman, modal usaha, kerja keras dan semangat serta ketekunan menjadi hal yang penting dan harus menjadi fokus dalam setiap pemberdayaan yang dilakukan.

Kegiatan pemberian daya sudah sangat banyak dilakukan di berbagai daerah baik tingkat kabupaten/kota maupun tingkat desa/kelurahan. Semua itu memiliki tujuan yang sama yaitu untuk mensejahterakan kehidupan masyarakat. Kegiatan pemberdayaan bukan sekedar membangun atau mendirikan sesuatu, akan tetapi kegiatan ini juga upaya memberikan pelatihan keterampilan, melakukan pendampingan, memberikan sumbangan/ hadiah, atau bentuk-bentuk kegiatan lainnya yang bertujuan untuk memberikan daya agar kesejahteraan masyarakat semakin meningkat. Mandiri, berdaya dan mampu berdiri di atas kaki sendiri merupakan target dari pemberdayaan masyarakat. Kebutuhan masyarakat lokal dan masyarakat setempat serta potensi masalah yang ada harus sesuai dengan bentuk pemberdayaan yang dicanangkan.

Pemberdayaan masyarakat adalah usaha mengubah perilaku masyarakat ke arah yang lebih baik, sehingga kualitas dan kesejahteraan hidupnya secara bertahap dapat meningkat. Sebagaimana dipaparkan dalam buku pemberdayaan masyarakat di era global, pemberdayaan masyarakat merupakan kegiatan yang mulia, sehingga pada tahapan ini dikatakan bahwa: masyarakat yang sudah berdaya membantu sesamanya yang tertinggal dan belum berdaya. Namun kompleksitas karakteristik masyarakat, terutama masyarakat yang belum berdaya tersebut, serta tuntutan zaman yang begitu pesat, merupakan peluang dan sekaligus tantangan bagi siapapun yang akan melakukan 
148 Esli Zuraidah Siregar, Pemberdayaan Masyarakat Melalui Kota Tanpa Kumuh Jurnal At-Taghyir : Jurnal Dakwah dan Pengembangan Masyarakat Desa

Volume 2 Nomor 1 Desember 2019, h. 147-162

pemberdayaan masyarakat. Oleh karena itu, kesuksesan dalam kegiatan pemberdayaan diperlukan agen pemberdayaan yang memiliki kompetensi sesuai tuntutan masyarakat dan perkembangan zaman. ${ }^{1}$

Pemberdayaan masyarakat tidak selalu berjalan lancar, terkadang ada kendalakendala yang dihadapi pada saat pelaksanaan, salah satunya masyarakat yang sulit untuk diajak berpartisipasi dalam setiap acara pemberdayaan yang dilaksanakan, hal ini bermula dari anggapan masyarakat bahwa pemberdayaan tidak menguntungkan. Dampak pemberdayaan masyarakat yang cenderung efek jangka panjang tidak cukup menarik bagi sebahagian masyarakat. Selanjutnya, kurangnya skill atau kemampuan masyarakat serta lemahnya pengetahuan masyarakat dalam bidang tersebut. Kurangnya motivasi masyarakat dalam melakukan perubahan merupakan merupakan salah satu kunci suksesnya sebuah program pemberdayaan. Seperti yang terjadi pada kegiatan program pemberdayaan masyarakat dalam pengurangan luasan kumuh dibeberapa daerah. Masyarakat awalnya kurang antusias untuk mengikuti kegiatan pemberdayaan masyarakat dalam pengurangan luasan kumuh yang dilakukan oleh lembaga pemerintah Kota Tanpa Kumuh (KOTAKU). Namun, setelah masyarakat diberi pengertian dan sosialisasi berkala oleh lembaga KOTAKU, akhirnya masyarakat bersedia berpartisipasi. Sosialisasi yang dilakukan memupuk rasa kesadaran masyarakat akan dampak/akibat yang diterima dari kegiatan pengurangan daerah kumuh. Pemberdayaan dalam mengurangi luasan kumuh bertujuan untuk menciptakan lingkungan yang bersih, sehat, indah serta menghadirkan suasanan yang nyaman bagi masyarakat.

Ketidak pahaman masyarakat tentang kegiatan pemberdayaan pengurangan luasan kumuh menimbulkan efek kurang antusias dan semangat masyarakat. Masyarakat tidak mengerti tentang program tersebut, sehingga masyarakat tidak mengetahuiapa yang harus dan akan dilakukan. Oleh karena itu, lembaga KOTAKU melakukan sosialisasi untuk mengajak masyarakat supaya berpartisifasi pada setiap kegiatan. Karena kegiatan tersebut didanai oleh pemerintah melalui lembaga KOTAKU sebagai usaha untuk mengurangi luasan kumuh. Kumuh adalah keadaan perlengkapan dan sarana pendukung pemukiman tidak sesuai dengan standar yang seharusnya. Standar yang ditetapkan merujuk pada keciptakaryaan dan sarana dan prasarana seperti

\footnotetext{
${ }^{1}$ Oos M. Anwas, Pemberdayaan Masyarakat di Era Global, (Bandung: Alfabeta, 2014), hlm. 3.
} 
149 Esli Zuraidah Siregar, Pemberdayaan Masyarakat Melalui Kota Tanpa Kumuh Jurnal At-Taghyir : Jurnal Dakwah dan Pengembangan Masyarakat Desa

Volume 2 Nomor 1 Desember 2019, h. 146-162

pemanganan kebarakaran, pengelolaan sampah, persediaan air bersih/minum yang menuhi standar kesehatan, pengelolaan limbah air, dan ruang publik terbuka dan dapat dimanfaatkan semua kalangan. Pemukiman kumuh adalah pemukiman yang digambarkan dengan kondisi hunian tidak layak tinggal, ketidakteraturan bangunan, padat penduduk dan kualitas penunjang pemukiman yang tidak sesuai aturan kelayakan pemukiman. Penanganan pemukiman kumuh sangat penting karena menyangkut hak dasar mendapatkan hidup yag lebih baik, menciptakan lingkungan yang baik dan berkualitas dan mencegah munculnya pemukiman kumuh lainnya.

Pemberdayaan masyarakat dalam pengurangan luasan kumuh dilakukan untuk mengurangi tingkat kumuh dan meningkatkan kualitas hidup masyarakat. Program kegiatan pemberdayaan masyarakat dalam pengurangan luasan kumuh dapat memperbaiki sistem kehidupan masyarakat, serta menjadikan hidup masyarakat berdaya, mandiri, memiliki skill dalam pengembangan dan akan berakibat pada peningkatan kesejahteraan masyarakat. Kegiatan pemberdayaan dalam pengurangan luasan kumuh biasanya berdasarkan hasil musyawarah dan mupakat antara Lembaga KOTAKU dengan masyarakat sekitar. Masyarakat akan diarahkan dalam pelaksanaan pengurangan luasan kumuh dengan melaksanakan pelatihan-pelatihan, mulai dari pelatihan pembuatan proposal sampai pada pelatihan keterampilan akan menghasilakn pengembangan masyarakat dilihat dari wawasan dan pengetahuannya meningkat.

\section{B. Pembahasan}

1. Pemberdayaan Masyarakat

Makna kata daya berarti kemampuan dalam melakukan sesuatu merupakan pengertian pemberdayaan secara etimologi. Imbuhan Pemberdayaan memiliki imbuhan yang bermakna melakukan sesuatu dan meningkatkannya. Berasal dari kata bahasa Inggris "empowerment". Menurut pendapat William, Webster, empowerment mempunyai dua makna, pertama, to give power of authority, yakni memberikan otoritas kekuatan pada pihak lain, sedangkan pada pengertia yang kedua adalah to give ability or enable yaitu usaha untuk member keberdayaan atau kemampuan. ${ }^{2}$ Pemberdayaan berusaha mencapai tujuan tanpa melupakan proses. Pemberdayaan sebagai proses adalah bagaimana sebuah kegiatan-kegiatan tersebut menilik pada pelaksanaannya.

\footnotetext{
2 Tamkin: Jurnal Pengembangan Masyarakat Islam Vol.3 No. 2 (2018), hlm. 110-130
} 
150 Esli Zuraidah Siregar, Pemberdayaan Masyarakat Melalui Kota Tanpa Kumuh Jurnal At-Taghyir : Jurnal Dakwah dan Pengembangan Masyarakat Desa

Volume 2 Nomor 1 Desember 2019, h. 147-162

Pemberdayaan bermakna tujuan merujuk pada hasil yang ingin diperoleh sesuai perencanaan awal, yakni memiliki daya dan meningkatkan kesejahteraan hidup masyarakat, mampu menyampaikan aspirasi, memiliki peluang usaha, dan memiliki mata pencaharian sebagai tumpuan hidup. ${ }^{3}$

Kekuasaan (power) dan pemberian kekuatan merupakan tujuan dan konsep dari sebuah Pemberdayaan (empowerment). Melakukan sesuatu berdasarkan harapan yang sesuai dengan kemampuan individu atau pun kelompok identik dengan kata pemberdayaan. Kemampuan mengatur kelompok, individu terutama kemampuan mengatur diri sendiri. Dengan artian, keinginan diri atau pengaruhnya dijadikan sebagai objek kekuasaan. Pendapat Djohani mengenai pemberdayaan dapat dibaca dalam kutipan berikut ini: suatu proses untuk memberikan daya/kekuasaaan (power) kepada pihak yang lemah (powerless), dan mengurangi kekuasaan (disempowered) kepada pihak yang terlalu berkuasa (powerful) sehingga terjadi keseimbangan. Begitu pula menurut Rapport bahwa pemberdayaan adalah suatu cara dengan mana rakyat, organisasi, dan komunitas diarahkan agar mampu menguasai atau berkuasa atas kehidupannya. $^{4}$

Berdasarkan paparan pengertian tersebut, penulis berasumsi bahwa pemberdayaan ialah sebuah proses dan pelaksanaan usaha untuk memberikan kekuatan, daya dan tenaga, kekuatan yang berakibat pada pengurangan masyarakat yang lemah (powerless) agar bisa menjadi masyarakat yang berdaya atau memiliki kekuatan (power) sehingga tercapai kesejahteraan masyarakat. Memberi wewenang, kekuasaan dan pengalihan kekuasaan harus menjadi sesuatu yang ditekankan dalam pengertian pemberdayaan (empowermant), sehingga kemampuan yang dimiliki dan potensi yang ada mampu mengendalikan lingkungan dan mengatur diri. Pihak yang lemah diberikan kekuasaan dan wewenang sehingga kehidupannya lebih sejahtera, merupakan tujuan utama pemberdayaan. Pemberdayaan tergantung pada proses pendidikan sebagai usaha untuk menambah nilai diri individu, kelurga maupun kelompok sosial sehingga mampu mengubah hidupnya lebih berdaya dan terpenuhinya kebutuhan-kebutuhan sehari-hari.

\footnotetext{
${ }^{3}$ Ibid., hlm. 110.

${ }^{4}$ Oos M. Anwas, Pemberdayaan Masyarakat di Era Global, (Bandung: Alfabeta, 2014), hlm.
} 49. 
151 Esli Zuraidah Siregar, Pemberdayaan Masyarakat Melalui Kota Tanpa Kumuh Jurnal At-Taghyir : Jurnal Dakwah dan Pengembangan Masyarakat Desa

Volume 2 Nomor 1 Desember 2019, h. 146-162

Menurut Parsons Pemberdayaan menuntut seseorang agar kehidupannya dan lingkungan sekitarnya terpengaruh melalui pengetahuan dan keterampilannya." ${ }^{\circ}$

Sebutan pemberdayaan, juga bisa dimaknai sebagai suatu usaha pemenuhan kebutuhan yang dibutuhkan masyarakat, baik individu maupun kelompok, agar lingkungannya terkontrol dan kemampuan untuk memilih peran terhadap sumber daya, pekerjaan, aktivitas sosial dapat dilakukan dengan leluasa sesuai potensi yang dimiliki. ${ }^{6}$ Masyarakat adalah sekelompok individu/manusia yang hidup disuatu tempat dalam waktu lama dan memiliki aturan-aturan yang harus dipatuhi sebagai anggotamsyarakat. Ada tiga hal yang menjadi persyaratan suatu daerah disebut masyarakat, yakni: (1). Sekelompok manusia yang berjumlah lebih dari 3 dalam artian banyak (2). Menempati daerah tertentu dalam kurun waktu yang tidak sebentar (3). Diikat oleh suatu hukum yang disepakati bersama.

Masyarakat merupakan makhluk sosial yang saling membutuhkan satu sama lain dan makhluk hidup yang tidak bisa hidup tanpa bantuan orang-orang disekitarnya. Manusia sering disebut sebagai makhluk hidup yang tidak bisa hidup tanpa orang lain disekitarnya (makhluk sosial). Saling membutuhkan dan berkelompok, hal ini yang menyebabkan manusia disebut dengan makhluk sosial. Selain defenisi diatas, ada beberapa defenisi masyarakat menurut beberapa ahli yaitu: Drs. JBAF Mayor Polak dikutip dari Abu Ahmadi mengatakan bahwa: Kelompok terdiri dari sub-sub kelompok serta kolektiva-kolektiva antar hubungan segenap masyarakat, atau dalam kata lain kelolpok yang terdiri dari kelompok-kelompok kecil. Prof. M.M Djojodiguno menjelaskan manusia yang hidup bersama dan berkembang antar satu manusia dengan manusia lainnya sehingga melahirkan sebuah peradaban. Kemudian Hasan Sadily mengatakan bahwa masyarakat adalah bersamanya sekumpulan manusia dan keadaan badannya.",7

Memiliki kebiasaan dan aturan yang mesti ditaaati dan hidup isuatu tempat dalam kurun waktu lama, dijelaskan dalam pengertian di atas. Pemikiran Khaldun dikutip dari Nanang Martono menjelaskan perbedaan dua jenis kelompok sosial yang

\footnotetext{
${ }^{5}$ Ibid, Oos M. Anwas, hlm. 49.

${ }^{6}$ Aprillia Theresia, dkk. Pembangunan Berbasis Masyarakat, (Bandung: Alfabeta, 2015), hlm. 116-117.

${ }^{7}$ Abu Ahmadi, Ilmu Sosial Dasar, (Jakarta: Rineka Cipta, 2009), hlm. 96-97.
} 
152 Esli Zuraidah Siregar, Pemberdayaan Masyarakat Melalui Kota Tanpa Kumuh Jurnal At-Taghyir : Jurnal Dakwah dan Pengembangan Masyarakat Desa

Volume 2 Nomor 1 Desember 2019, h. 147-162

dianggap berbeda karakter yaitu: Kelopok tersebut memiliki dua kategori yang harus dimiliki, pertama, "badawah", yaitu Sekelompok masyarakat primitive yang bermukim di daerah tertinggal seperti gurun pasir, hutan rimba, dan berusah bertahan hidup langsung dari hasil bumi. Kedua, "hadharah", yaitu masyarakat peradaban atau masyarakat yang hidup di daerah perkotaan. Menurut khaldun kehidupan masyarakat kota identik dengan kemewahan, mengikuti hawa nafsu. Akhlaknya sudah terkontaminasi dengan sifat tercela. Hal ini dibandingkn dengan masyarakat badui yang masih berusaha berbuat sesuai batasa-batas diri mereka sebagai hamba yang bertuhan, meski dalam kemewahan, kesenangan dan hawa nafsu. Kebutuhan masyarakat dipertahankan dan dijadikan kunci utama dalam menjelaskan solidaritas, hal ini dijelaskan dalam buku Muqaddimah karya Khaldun. ${ }^{8}$

Lain halnya dengan Soerjono Soekanto yang memaparkan tentang kehidupan masyarkat memiliki ciri-ciri antara lain: (a). Individu yang hidup bersama dan tinggal bersama disuatu daerah lebih dari satu individu (b). Berinteraksi dan berbaur dengan kurun waktu lama. Hubungan antar individu akan timbul dan berlangsung dari peraturan yang mengatur serta sistem komunikasi karena interaksi dan percampuran masyarakat dalam kurun waktu lama. (c). Satu kesatuan kehidupan harus disadari setiap individu. (d). Saling terkait antara individu yang satu dengan individu yang lain yang timbul karena budaya dan sistem yang dibuat bersama. ${ }^{9}$ Dari berbagai penjelasan tersebut, mengatasi masalah dengan berbagai kegiatan-kegiatan yang diajukan dalam rangka untuk membahas pembangunan sebagai masalah utama dengan melibatkan masyarakat sebagai orang yang diberi kepercayaan dan berpartisipasi dalam setiap proses kegiatan yang bertujuan meningkatkan kesejahteraan disebut dengan pemberdayaan. Pemberdayaan selanjutnya menjadi sebuah program yang berbasis Nasional, daerah dan juga regional. Fasilitator sebagai lembaga pendukung dan yang menjadi penentu dari sebuah pemberdayaan adalah masyarakat itu sendiri. Manfaat pemberdayaan masyarakat mencakup masyarakat luas.

\footnotetext{
${ }^{8}$ Nanang Martono, Sosiologi Perubahan Sosial: Perspektif Klasik, Modern, Posmodern, dan Poskolonial, (Jakarta: PT RajaGrafindo Persada, 2012), hlm. 32.

9 Elly M. Setiadi dan Usman Kolip, Pengantar Sosiologi: Pemahaman Fakta dan Gejala Permasalahan Sosial: Teori, Aplikasi, dan Pemecahannya, (Jakarta: Kencana, 2011), hlm. 36-37.
} 
153 Esli Zuraidah Siregar, Pemberdayaan Masyarakat Melalui Kota Tanpa Kumuh Jurnal At-Taghyir : Jurnal Dakwah dan Pengembangan Masyarakat Desa

Volume 2 Nomor 1 Desember 2019, h. 146-162

Manfaat pemberdayaan dan pengembangan masyarakat berdasarkan kategorinya diterima oleh: (1) Unsur utama yang terdiri dari keluarga dan warga atau kelompok masyarakat. (2) Pemerintah dan aparat birokrasi memiliki peran sebagai penentu kebijakan. Yang bertugas sebagai perancang program serta yang mengandalikan kebijakan (3). Pendukung kegiatan lainnya, yang memiliki kepentingan seperti BKM dan Fasilitator. Bersifat komunitas dan individu adalah fokus pemberdayaan. Terciptanya kemandirian dari daya yang dimiliki setiap individu meningkatkan motivasi keterampilan, pengalaman individu adalah suatu proses dalam pemberdayaan. Seorang individu dikatakan berdaya apabila ia mampu berdiri sendiri, berperan aktif dalam pembangunan, mampu memimpin, memiliki keinginan yang kuat dan berdaya saing sesuai potensi hal ini meripakan bentuk pemberdayaan secara individu, sedangkan sifat pemberdayaan kelompok atau komunitas adalah mampu mengkondisikn kelompok tersebut untuk melaksanakan setiap program yang direncanakan sehingga kelompok tersebut semakin sejahtera dan mandiri.

Pemberdayaan bukan semata-mata melihat hasil akhir, namun menekankan pada proses pelaksanaan atau proses terjadinya kegiatan. Keberdayaan individu dan kelompok masyarakat serta partisipasi masyarakat menjadi salah satu ukuran keberhasilan pemberdayaan. Banyak jumlah orang yang terlibat maka kemumngkinan besar kegiatan tersebut akan berhasil. Sebagaimana dipaparkan dalam ayat 11 dalam surat Surah Ar-Ra'd:

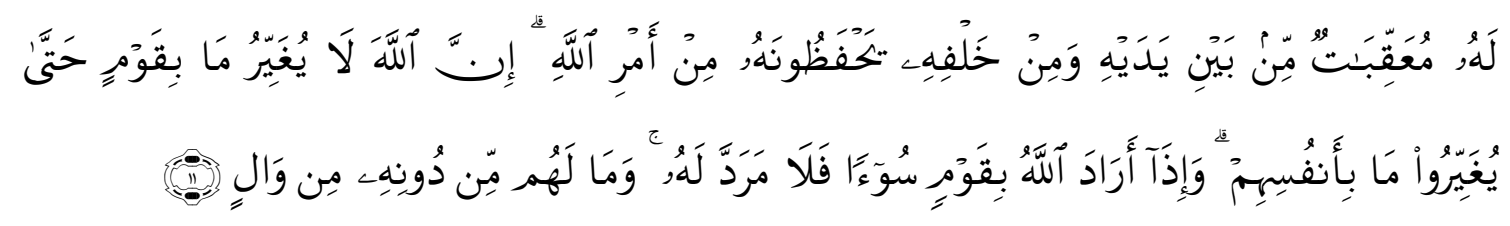

"Bagi manusia ada malaikat-malaikat yang selalu mengikutinya bergiliran, di muka bumi dan di belakangnya, mereka menjaganya atas perintah Allah. Sesungguhnya Allah tidak akan mengubah keadaan suatu kaum sehingga mereka mengubah keadaan yang ada pada diri mereka sendiri. Dan apabila Allah menghendaki keburukan terhadap sesuatu kaum, maka tak ada yang dapat menolaknya; dan sekali-kali tak ada pelindung bagi mereka selain Dia."

${ }^{10}$ Departemen Agama RI, Al-Qur'-an dan Terjemahannya 1-juz 10, (Bandung: CVJ-ART, 2004), hlm 250 
154 Esli Zuraidah Siregar, Pemberdayaan Masyarakat Melalui Kota Tanpa Kumuh Jurnal At-Taghyir : Jurnal Dakwah dan Pengembangan Masyarakat Desa

Volume 2 Nomor 1 Desember 2019, h. 147-162

Dari ayat di atas menurut hemat penulis bahwa agar terjadi perubahan di suatu masyarakat maka masyarakat sendirilah yang harus berusaha untuk mengubah keadaan kehidupan dimasyarakat itu sendiri, melalui kerja sama dan tentunya untuk mencapai suatu perubahan harus melalui proses dan tidak langsung kepada hasil atau output. Sebagaimana dalam buku Pengembangan Masyarakat: Wacana dan Praktik dikatakan bahwa: Meminjam Teori Kepribadian Kreatif yang dikembangkan oleh Everette Hagen, proses perubahan yang berlangsung secara bertahap. Kejadian yang berlangsung berhubungan dengan keatifitas indivu. Individu yang berkepribadian kreatif tidak tersebar dalam proporsi dan kadar yang sama dalam setiap masyarakat. Menurut Soetomo, masyarakat di negara-negara berkembang (mayoritas dalam kondisi miskin) dinilai mempunyai anggota yang berkepribadian kreatif dalam proporsi yang kecil, sehingga mengakibatkan kurangnya inisiatif dan kreativitas menuju perubahan. ${ }^{11}$

Menurut Heraclitus dan Susanto mencermati bahwa yang abadi di bumi ini hanyalah perubahan, selainnya akan berubah sesuai roda perubahanna masing-masing, tidak ada yang abadi dimuka bumi ini, kecuali perubahan. Selanjutnya Rose dan Nicholl juga mengatakan bahwa: Perubahan adalah sesuatu yang pasti terjadi sampai akhir zaman. Dalam bidang ilmu pengetahuan, di dunia ini pengetahuan meningkat dua kali lipat setiap dua atau tiga tahun dalam hampir setiap lapangan pekerjaan.Ini berarti pengetahuan yang kita miliki juga harus meningkat dua kali lipat setiap dua atau tiga tahun kalau ingin bertahan dan menyesuaikan dengan perkembangan zaman. ${ }^{12}$

Dalam suatu kegiatan di suatu daerah harus saling mendukung dan bekerjasama antara satu sama lain agar tercapai kegiatan yang dimaksud. Begitu jugapada kegiatan pemberdayaan pada dasarnya pengembangan masyarakat adalah suatu unsur-unsur terkait mendukung masyarakat untuk melakukan pembangunan sosial, seperti dari pemerintah, LSM, organisasi sosial, masyarakat, dan juga media massa. Dalam berbagai kesempatan pakar pemberdayaan Prof. Haryono Suyono sering mengatakan bahwa pemberdayaan bukan membentuk supermen, tetapi dalam pemberdayaan perlu membentuk super tim. ${ }^{13}$ Super tim yang memiliki prinsip atau berprinsip.

${ }^{11}$ Zubaedi, Pengembangan Masyarakat Wacana dan Praktik, (Jakarta: Kencana Prenadamedia Group, 2012), hlm. 221.

12 Ibid, Oos M. Anwas hlm. 4.

${ }^{13}$ Ibid., hlm. 51. 
155 Esli Zuraidah Siregar, Pemberdayaan Masyarakat Melalui Kota Tanpa Kumuh Jurnal At-Taghyir : Jurnal Dakwah dan Pengembangan Masyarakat Desa

Volume 2 Nomor 1 Desember 2019, h. 146-162

Berdasarkan hasil identifikasi menyatakan bahwa ada beberapa prinsip pemberdayaan masyarakat, hal ini diharapkan menjadi acuan pelaksanaan pemberdayaan secara real dan benar:

a. Menghindari unsur paksaan dan berusaha bersikap demokratis dalam pelaksanaan pemberdayaan, karena berdaya adalah hak yang sama bagi setiap individu. Perbedaan disetiap individu merupakan hal yang lumrah, karena manusia diciptakan unik dan berbeda antara satu dengan yang lainnya, baik dari minat, bakat, potensi, kebustuhan dan masalah yang dihadapinya. Pemberdayaan tidak mencontohkan atau membenarkan unsur paksaan karena hal tersebut bukan bagian dari pemberdyaan.

b. Dasar kegiatan pemberdayaan adalah sasaran/ potensi klien, kebutuhan dan potensi. Hakikatnya, setiap manusia memiliki kebutuhan dan potensi dalam dirinya. Proses pemberdayaan dimulai dengan menumbuhkan kesadaran kepada sasaran akan potensi dan kebutuhannya yang dapat dikembangkan dan diberdayakan untuk mandiri. Proses pemberdayaan juga dituntut berorientasi kepada kebutuhan dan potensi yang dimiliki sasaran. Biasanya pada masyarakat pedesaan yang masih tertutup, aspek kebutuhan, masalah, dan potensi tidak nampak. Agen pemberdayaan perlu menggali secara tepat dan akurat. Dalam hal ini agen pemberdayaan perlu memiliki potensi untuk memahami potensi dan kebutuhan klien/sasaran.

c. Pelaku dan subjek menjadi sasaran utama pemberdayaan. Oleh karena itu sasaran menjadi dasar pertimbangan dalam merancang tujuan, pendekatan, dan bentuk aktivitas pemberdayaan.

d. Beberapa hal yang menjadi nilai luhur dalam masyarakat seperti kearifan-kearifan local, nilai dan budaya menjadi tujuan pemberdayaan untuk menumbuhkannya kembali. Budaya dan kearifan lokal seperti sifat gotong royong, kerjasama, hormat kepada yang lebih tua, dan kearifan lokal lainya sebagai jati diri masyarakat perlu ditumbuhkembangkan melalui berbagai bentuk pemberdayaan sebagai modal sosial dalam pembangunan.

e. Belajar terus menerus dengan tujuan meningkatkan potensi dilakukan dalam rangka memberdayakan masyarakat, belajar sepanjang hayat (lifelong learning education). Individu dan masyarakat perlu dibiasakan belajar menggunakan berbagai sumber 
156 Esli Zuraidah Siregar, Pemberdayaan Masyarakat Melalui Kota Tanpa Kumuh Jurnal At-Taghyir : Jurnal Dakwah dan Pengembangan Masyarakat Desa

Volume 2 Nomor 1 Desember 2019, h. 147-162

yang tersedia. Sumber belajar ysng dimaksud bisa dalam bentuk lingkungan sekitar, bahan, alat, teknik serta manusia dan pesan yang disampiakannya. Prinsip belajar sambil bekerja menekannya proses dari pemberdayaan itu sendiri.

f. Memperhatikan keragaman budaya dalam pemberdayaan perlu dilakukan. Kondisi di lapangan harus menjadi acuan untuk menentukn pendekatan dan metode pemberdayaan.

g. Masyarakat seluas-luasnya serta individu diharapkan pastisipasi aktif yang digerakkan oleh pemberdayaan dan pengembangan masyarakat. Partisipasi ini mulai dari tahapan perencanaan, pengembangan, pelaksanaan, evaluasi, termasuk partisipasi dalam menikmati hasil dari aktivitas pembedayaan. Aktivits pemberdayaan dinikmati hasilnya setelah melalui tahapan-tahapan pemberdayaan, yakni rencana (perencanaan), pengembangan, pelaksanaan, evaluasi serta seluruh rangkaian kegiatan membutuhkan partisipasi masyarakat.

h. Memiliki bekal kemandirian dan menumbuhkan jiwa kewirausahaan dijadikan sebagai sasaran pemberdayaan. Di era globalisasi diperlukan jiwa-jiwa yang memiliki kemauan mengembangkan networking, mencari peluang dan memenfaatkannya, berani mengambil resiko, dan memiliki banyak inovasi.

i. Kompetensi agen perubahan atau petugas pemberdayaan harus mendukung dan memiliki kemampuan serta mampu mengikuti perkembangan zaman, karena. seorang agen akan dituntut sebagai fasilitator pembedayaan masyarakat.

Banyak pihak yang harus dilibatkan dalam proses atau pelaksanaan pemberdayaan sesuai peran dan potensinya. ${ }^{14}$ Hal itu terjadi karena banyak strategi yang digunakan dan membutuhkan pelaksanaan pemberdayaan yang memiliki potensi di bidangnya. Berbagai pendekatan perlu dilakukan dalam pelaksanaan pemberdayaan dan pengembangan masyarakat, hal ini juga dijelaskan oleh Suharto, yang melakukan pemberdayaan melalui 5P: "Pemungkinan, penguatan, perlindungan, penyokongan, dan pemeliharaan, dengan penjelasan sebagai berikut:

a) Pemungkinan; menciptakan suasana atau iklim yang memungkinkan potensi masyarakat berkembang secara optimal. Pemberdayaan harusmampu membebaskan masyarakat dari sekarat-sekarat kultural dan struktur yang menghambat.

\footnotetext{
${ }^{14}$ Oos. M. Anwas, Op. Cit., hlm. 58-60.
} 
157 Esli Zuraidah Siregar, Pemberdayaan Masyarakat Melalui Kota Tanpa Kumuh Jurnal At-Taghyir : Jurnal Dakwah dan Pengembangan Masyarakat Desa

Volume 2 Nomor 1 Desember 2019, h. 146-162

b) Penguatan; memperkuat pengetahuan dan kemampuan yang dimiliki masyarakat dalam memecahkan masalah dan memenuhi kebutuhan-kebutuhannya. Pemberdayaan harus mampu menumbuhkembangkan segenap kemampuan dan kepercayaan diri masyarakat yang menunjang kemandirian mereka.

c) Perlindungan; melindungi kelompok lemah, melindungi masyarakat terutama kelompok-kelompok lemah agar tidak tertindas oleh kelompok kuat, menghindari terjadinya persaingan yang tidak seimbang (apalagi tidak sehat) antara yang kuat dan lemah, dan mencegah terjadinya eksploitasi kelompok kuat terhadap kelompok lemah. Pemberdayaan harus diarahkan kepada penghapusan segala jenis diskriminasi dan dominasi yang tidak menguntungkan rakyat kecil.

d) Penyokongan; memberikan bimbingan dan dukungan agar masyarakat mampu menjalankan perannya dan tugas-tugas kehidupannya. Pemberdayaan harus mampu menyokong masyarakat agar tidak terjatuh ke dalam keadaan dan posisi yang semakin lemah dan terpinggirkan.

e) Pemeliharaan; memelihara kondisi yang kondusif agar tetap terjadi keseimbangan distribusi kekuasaan antara berbagai kelompok dalam masyarakat. Pemberdayaan harus mampu menjamin keselarasan dan keseimbangan yang memungkinkan setiap orang memperoleh kesempatan berusaha."15

2. Kota Tanpa Kumuh

Program Kota Tanpa Kumuh (KOTAKU) dilaksanakan di 271 Kabupaten/Kota di 34 Propinsi sebagai "Platform Kolaborasi” program ini dilaksanakan secara Nasional sebagai sebuah usaha untuk menangani pemukiman kumuh diintegrasikan pada pemangku kepentingan, masyarakat, masyarakat swasta, kabupaten, kota, propinsi dan pemerintah pusat serta berbagai sumber daya dan pendanaannya. Kota Tanpa Kumuh mengedepankan partisipasi masyarakat, implementasi, perencanaan dan pemangku kepentingan yang dikolaborasikan untuk membangun dan menangani pemukiman kumuh dibeberapa kota/kabupaten di Indonesia. Sasaran RPJMN 2015-2019 tentang kota tanpa kumuh dicapai dengan perbaikan infastruktur, pelayanan dasar tingkat kota maupun tingkat masyarakat, perencanaan, penguatan kelembagaan dan pengembangan

${ }^{15}$ Oos M. Anwas, Pemberdayaan Masyarakat di Era Global, (Bandung: Alfabeta, 2014), hlm. $87-88$. 
158 Esli Zuraidah Siregar, Pemberdayaan Masyarakat Melalui Kota Tanpa Kumuh Jurnal At-Taghyir : Jurnal Dakwah dan Pengembangan Masyarakat Desa

Volume 2 Nomor 1 Desember 2019, h. 147-162

kapasitas pemerintah daerah dan masyarakat di Indonesia yang dilaksanakan secara bertahap untuk penanganan pemukiman kumuh dengan luas 35.291 Ha.

Syarat sarana dan prasaranan secara ideal tidak memenuhi merupakan unsur daerah tersebut dikatakan kumuh. Ukuran memadainya sarana dan prasarana dilihat dari adanya pengaman kebakaran, memiliki ruang public sesuai standar yang ditetapkan, memiliki pengelolaan limbah air, jalan perkampungan yang aman sesuai standar, serta drainase yang tidak mengganggu dan meresahkan masyarakat. Memperbaiki akses masyarakat, infrastruktur serta pemukiman sesuai indicator $1+7 / 7+1$ Pemukiman kumuh:

a) Gedung berbentuk bangunan yaitu, bentuk, orientasi dan dimensi tidak tertata rapi/teratur. ketidakteraturan dalam hal dimensi, orientasi, dan bentuk. Rencana tata ruang tidak sesuai dengan kepadanan, system strukturan tidak memenuhi syarat teknis secara baku, pengamanan petir, penghawaan, pencahayaan, sanitasi, dan bahan bangunan.

b) Jalan pemukiman, jalan pemukiman yang tidak memadai mengakibatkan kendaraan tidak dapat melaluinya dengan nyaman dan aman. Keamanan dan kelengkapan lalu lintas tidak memenuhi standar serta ukuran jalan yang tidak memadai.

c) Persediaan air bersih, kebutuhan air bersih setiap individu dan keluarga tidak sesuai dengan standar kesehatan dan aksesnya yang mendukung.

d) Drainase lingkungan, yaitu saluran pembuangan air/selokan di kelurahan tidak mampu menampung luapan air hujan dan tidak terintegrasi pada sistem pembuangan atau drainase diperkotaan.

e) Limbah air yang dikelola tidak sesuai standar yang berlaku dapat dapat menyebabkan lingkungan pemukiman tercemari.

f) Sarana dan prasarana pengolahan sampah yang tidak tersedia dan motivasi masyarakat untuk mengolah sampah rumah tangga dapat merusak keindahan dan keasrian lingkungan.

g) Perlengkapan pengamanan kebakaran masih jauh dari standar operasional yaitu, kurangnya pasokan air, akses jalan yang sempit, dan mobil pemadam kebakaran yang terbatas. 
159 Esli Zuraidah Siregar, Pemberdayaan Masyarakat Melalui Kota Tanpa Kumuh Jurnal At-Taghyir : Jurnal Dakwah dan Pengembangan Masyarakat Desa

Volume 2 Nomor 1 Desember 2019, h. 146-162

h) Ruang terbuka public, yaitu lahan untuk ruang terbuka hijau (RTH) tidak tersedia, ketidaktersediaan lahan untuk ruang terbuka non-hijau/ruang terbuka publik (RTP). ${ }^{16}$

\section{Pemberdayaan Masyarakat Melalui Program KOTAKU}

Pemberdayaan dalam konteks masyarakat merupakan kemampuan individu berpartisipasi aktif dalam masyarakat. Tingkat partisipasi ini meliputi partisipasi secara fisikdan non fisik dengan tujuan memperoleh manfaatbagi individu yang bersangkutan. Adapun indikator pelaksanaan program pemberdayaan masyarakat melalui pembangunan infrastruktur dalam pengurangan luasan kumuh, yaitu Aspek pendidikan, Sektor penting dalam mengubah perilaku manusia keaarah yang lebih baik.

Menurut Benyamin, perilaku masyarakat belum dapat dikategorikan dalam tiga aspek yaitu pengetahuan, sikap dan keterampilan. Pemberdayaan hakikatnya adalah terubahnya perilaku masyarakat. Mengubah perilaku dimulai dari mengubah cara berpikir (mind set) dari pengetahuan dan pemahamannya, selanjutnya diharapkan memiliki sikap yang positif untuk berubah, selanjutnya diwujudkan dalam perilaku nyata sebagai bentuk usaha untuk mengubah perilaku ke arah yang lebih baik menuju pada peningkatan kualitas dan kesejahteraan. ${ }^{17}$

Pemberdayaan Melalui KOTAKU dari aspek pendidikan dilakukan melalui pembangunan dan perbaikan sarana dan prasarana sekolah yang terdapat di wilayah terkait. Memenuhi segala fasilitas yang dibutuhkan sekolah-sekolah di daerah sekitar. Program ini dilaksanakan dengan melibatkan masyarakat sebagai pemeran utama serta pejabat pemerintah dan pemangku kepentingan di wilayah tersebut. Di beberapa daerah pemberdayaan masyarakat melalui aspek pendidikan dilakukan dengan pemberian beasiswa kepada siswa kurang mampu namun memiliki prestasi yang gemilang, pemberian bantuan perlengkapan sekolah seperti buku paket, buku tulis dan perlengkapan lainnya. Pembangunan perpustakan yang tidak hanya bisaa dijangkau oleh sisa-siswinya, namun bisa dijangkau oleh masyarakat pada umumnya.

Aspek kesehatan, melakukan aktualisasi dan habituasi terhadap aksi nyata yang bisa dilakukan oleh masyarakat dalam kehidupan keseharian. Kegiatan tersebut antara lain: membersihkan di lingkungan sekitar rumah masing-masing, membuat tempat

\footnotetext{
${ }^{16}$ Pedoman Umum Kotaku (Kota Tanpa Kumuh).

${ }^{17}$ Ibid, Oos M. Anwas. hlm. 115.
} 
160 Esli Zuraidah Siregar, Pemberdayaan Masyarakat Melalui Kota Tanpa Kumuh Jurnal At-Taghyir : Jurnal Dakwah dan Pengembangan Masyarakat Desa

Volume 2 Nomor 1 Desember 2019, h. 147-162

sampah dan menyepakati bersama untuk membuang sampah pada tempatnya, membuat atau membersihkan saluran air secara bergotong royong, membersihkan pekarangan dan jalan sekitar lingkungan, dan kegiatan lainnya. Pada akhirnya hasil program pemberdayaan pada aspek kesehatan masyarakat menjadi sebuah budaya hidup sehat dalam keluarga dan masyarakat. Sehingga menciptakan kesejahteraan dalam bidang kesehatan. ${ }^{18}$ Lingkungan yang bersih melahirkan lingkungan yang indah dan sehat, lingkungan kumuh dengan sampah dan kotoran-kotoran menyebabkan berbagai penyakit akan menyerang masyarakat, oleh karena itu habituasi akan menciptakan lingkungan yang indah dan sehat.

Aspek Sumber daya manusia, sumber daya manusia merupakan modal yang sangat penting dalam melaksanakan pembangunan. Keterkaitan masalah ini dengan pemberdayaan masyarakat sangat besar. Dampak pemberdayaan masyarakat adalah kemandirian masyarakat dalam mengatasi permasalahan mereka melalui prakarsa dan kreatifitas untuk meningkatkan kualitas hidup. Tentunya membutuhkan masyarakat yang mempunyai pengetahuan, keterampilan, dan sikap untuk keluar dari permasalahan mereka. Kemandirian adalah sikap yang bersumber pada kepercayaan diri. Kemandirian juga adalah kemampuan (mental dan fisik) untuk memahami kekuatan dan kelemahan diri sendiri, memperhitungkan kesempatan dan ancaman lingkungan, dan sekaligus mengembangkan kehidupan secara serasi dan berkesinambungan. Jelas kiranya bahwa pemberdayaan pada akhirnya bukan hanya sekedar berorientasi pada proses tetapi juga pada hasil itu sendiri. ${ }^{19}$

Aspek kenyamanan lingkungan, dampak/hasil pelaksanaan program pemberdayaan masyarakat untuk mengurangi luasan kumuh berupa penanganan drainase, menciptakan lingkungan aman, baik terhadap genangan maupun luapan sungai, banjir kiriman dan hujan lokal. Kemudian meningkatkan kesehatan lingkungan, bila drainase lancar maka memperkecil resiko penyakit yang ditranmisikan melalui air (water borne disease) dan penyakit lainnya. Sistem drainase yang baik tataguna lahan

\footnotetext{
${ }^{18}$ Ibid, Oos. M. Anwas. hlm. 121.

19 MG Ana Budi Rahayu, "Pembangunan Perekonomian Nasional Melalui Pemberdayaan Masyarakat Desa," hlm. 8. Diakses tanggal 13 Mei 2019. Pukul 20:00 WIB.
} 
161 Esli Zuraidah Siregar, Pemberdayaan Masyarakat Melalui Kota Tanpa Kumuh Jurnal At-Taghyir : Jurnal Dakwah dan Pengembangan Masyarakat Desa

Volume 2 Nomor 1 Desember 2019, h. 146-162

dapat dioptimalkan dan juga memperkecil kerusakan-kerusakan sruktur tanah untuk jalan dan bangunan-bangunan lainnya. ${ }^{20}$

\section{Kesimpulan}

Pemberdayaan Kota Tanpa Kumuh (KOTAKU) merupakan pemberdayaan yang dilakukan secara Nasional untuk mengurangi Luasan kumuh 271 Kabupaten/Kota di 34 Propinsi yang berbasis penanganan pemukiman kumuh yang terintegrasi berbagai sumber daya dan pendanaan. Program pengurangan luasan kumuh dilakukan dengan kolaborasi antara pemangku kepentingan dengan pemerintah daerah sebagai pimpinan dalam membangun suatu sistem penanganan dan pengurangan luasan kumuh. Indikator Pengurangan Luasan Kumuh terdiri dari berbagai Aspek, yakni; Aspek pendidikan, Aspek kesehatan, Sumber daya manusia dan Aspek kenyamanan lingkungan. Aspek pemberdayaan tersebut merupakan unsur yang saling berkaitan antara satu sama dengan tujuan memberikan daya kepada masyarakat, sehingga Luasan kumuh di Indonesia menurun untuk tahun-tahun selanjutnya.

\section{Daftar Kepustakaan}

Anwas, Oos M. 2014. Pemberdayaan Masyarakat di Era Global. Bandung: Alfabeta. Tamkin: Jurnal Pengembangan Masyarakat Islam Vol.3 No. 2 (2018) Theresia, Aprillia dkk. 2015. Pembangunan Berbasis Masyarakat, Bandung: Alfabeta. Soekanto,Soerjono. 1990. Sosiologi Suatu Pengantar. Jakarta: Grafindo Persada. Ahmadi, Abu. 2012. Ilmu Sosial Dasar. Jakarta: Rineka Cipta.

Martono, Nanang. 2012. Sosiologi Perubahan Sosial: Perspektif Klasik, Modern, Posmodern, dan Poskolonial. Jakarta: PT RajaGrafindo Persada.

Martono, Elly M. Martono, dan Kolip, Usman. 2011. Pengantar Sosiologi: Pemahaman Fakta dan Gejala Permasalahan Sosial: Teori, Aplikasi, dan Pemecahannya. Jakarta: Kencana.

Departemen Agama RI. 2012. Al-Qur'an dan Terjemahnya Juz 1- Juz 30. Bandung: CV J- ART.

Zubaedi. 2012. Pengembangan Masyarakat Wacana dan Praktik. Jakarta: Kencana PRENADAMEDIAGROUP.

Budi Rahayu. MG Ana "Pembangunan Perekonomian Nasional Melalui Pemberdayaan Masyarakat Desa" 13 Mei 2019.

Direktorat Pengembangan Pemukiman. Direktorat Jenderal Cipta Karya Departemen Pekerjaan Umum. 2006. Konsep Pedoman Identifikasi Kawasan Pemukiman Kumuh Penyangga Kota Metropolitan: Jakarta.

${ }^{20}$ Rencana Program Investasi Jangka Menengah Bidang PU/CIPTAKARYA, "Buku Panduan Penyehatan Lingkungan Permukiman," hlm. 83 
162 Esli Zuraidah Siregar, Pemberdayaan Masyarakat Melalui Kota Tanpa Kumuh Jurnal At-Taghyir : Jurnal Dakwah dan Pengembangan Masyarakat Desa

Volume 2 Nomor 1 Desember 2019, h. 147-162

Keputusan Menteri Pemukiman dan Prasaranan Wilayah. 2002: Pedoman Teknis Pembangunan Rumah Sederhana Sehat. Nomor: 403/KPTS/M/2002.

Sri Yuniani, Gusti Putri Dhini Rosyida. "Kolaborasi Dalam perencanaan Program Kota Tanpa Kumuh (KOTAKU) di Kelurahan Semanggi Kota Surabaya" dalam Jurnal Wacana Publik Vo. 1 No. 2 Tahun 2017

Suharto, Edi. 2010. Membangun Masyarakat memberdayakan Rakyat. Yogyakarta: Pustaka Pelajar.

Undang-undang Republik Indonesia No.1 tahun 2011 tentang Perumahan dan Kawasan Pemukiman

Wijayanti, Kurnia, Sjamsiar, Muchamad Rozikin. "Upaya Badan Keswadayaan Msyarakat (BKM) Dalam Pemberdayaan Masyarakat" dalam Jurnal Aministrasi Publik (JAP). Vol. 10. 